\title{
Variation in morphological traits of a selection of Indonesian winged bean accessions (Psophocarpus tetragonolobus) and its analysis to assess genetic diversity among accessions
}

\author{
IZMI YULIANAH ${ }^{1,2}$, BUDI WALUYO ${ }^{2}$, SUMERU ASHARI ${ }^{2}$, KUSWANTO ${ }^{2, v}$ \\ ${ }^{1}$ Graduate Program, Faculty of Agriculture, Universitas Brawijaya. J1. Veteran, Malang 65145 East Java, Indonesia \\ ${ }^{2}$ Department of Agronomy, Faculty of Agriculture, Universitas Brawijaya. Jl. Veteran, Malang 65145, East Java, Indonesia. Tel.: + 62-341-569984, \\ "email: kuswantoas@ub.ac.id
}

Manuscript received: 22 April 2020. Revision accepted: 8 June 2020.

\begin{abstract}
Yulianah I, Waluyo B, Ashari S, Kuswanto. 2020. Variation in morphological traits of a selection of Indonesian winged bean accessions (Psophocarpus tetragonolobus) and its analysis to assess genetic diversity among accessions. Biodiversitas 21: 2991-3000. In Indonesia, winged bean (Psophocarpus tetragonolobus (L.) DC.) is a traditional vegetable crop grown mainly for its edible green pods. Plant breeding programs aim to produce cultivars with high production and good nutritional qualities. The objective of this present study was to assess genetic diversity among 21 selected Indonesian winged bean lines based on observation of morphological characters. This was the first step in determining an appropriate breeding program for the development of improved vegetable cultivars. Twelve qualitative characters and eight quantitative variables were assessed for each of the 21 lines. Categorical differences among lines were observed in characters such as leaflet, pod and seed shape, pod surface texture, anthocyanin pigmentation of stem, flowers and pods. Several of these characters are useful as genetic markers, and cluster analysis of the 21 lines on the basis of qualitative characters enabled two distinct groupings to be identified. Quantitative variation across line means was also high for several of the quantitative variables (a coefficient of variation $>25 \%$ for pod length, number of pods per plant, and total pod weight per plant). Principal component analysis applied to the eight variables accounted for $86 \%$ of the total variation in just three components with eigenvalues $>1$. On Component 1, the characters number of days to first open flower, pod length and pod weight were closely aligned with total weight of pods per plant. Number of pods per plant was not closely aligned with weight of pods per plant. This study has enabled broad differences between groups of lines to be categorized and has identified particular lines with characteristics that recommend them for inclusion as parents in inheritance studies designed to elucidate the contribution that individual characters make to overall productivity, attractiveness, and nutrition of this useful, high protein, vegetable species.
\end{abstract}

Keywords: genetic diversity, Indonesian, morphological characters, plant breeding, winged bean

\section{INTRODUCTION}

Indonesia is recognized as one of the genetic diversity centers for winged bean. However, the area planted to winged bean in Indonesia appears not to have expanded beyond what it was when Thompson and Haryono (1980) wrote their optimistic report. Cultivation still uses traditional low input methods, and currently, winged bean is best considered as a backyard plant, its utilization being limited to household consumption (Handayani 2013).

For the most part, winged bean landraces in Indonesia are facultative perennials. They can be planted both in rainy and dry seasons, with a capacity to produce vegetable pods in low to moderate quantities over several seasons if allowed. Winged beans planted in the rainy season produce more leaf but fewer flowers and pods (Kuswanto et al 2016). The abundance of leaves during the vegetative phase appears to inhibit the transition to the generative phase, resulting in a long, drawn out harvest time. The time from planting to first harvestable pod in winged bean is often almost twice as long as for other popular leguminous vegetable species; i.e. 13-14 weeks for winged bean, compared to just 8-9 weeks for crops like common bean
(Phaseolus vulgaris L.) and yardlong bean (Vigna unguiculata L. Walp. subsp. sesquipedalis (Eagleton 2019). Several approaches have been carried out with the aim of increasing winged bean pod and seed production. Throughout the traditional growing areas in tropical Asia and Melanesia, winged beans are indeterminate climbers in growth habit, so one avenue of research has been to attempt to manipulate biomass production by such things as adjustments to trellising support and vegetative pruning with the aim of stimulating flower and pod production. Using two-metre high trellising, ratooning, and multiple harvesting over an extended time, period Wong (1980) and (Motior et al (1998b) have reported obtaining very high green pod yields and seed yields of $35 \mathrm{t} / \mathrm{ha}$ and $6.26 \mathrm{t} / \mathrm{ha}$ respectively, but the cost of the trellising is high. Another approach has been to use plant breeding methods to generate varieties with modified plant architecture, particularly branching pattern, with a view to maximizing pod set (Tanzi et al. 2019). Approaches using plant breeding have included classification of genetic diversity across the species (Khan 1976; Eagleton et al. 1980; Mohamadali and Madalageri 2015; Handayani et al. 2015); expansion of genetic diversity through the induction of 
genetic mutations (Klu et al. 1997); baseline inheritance studies (Erskine and Khan 1977; Erskine 1980; Erskine 1981); hybridisation followed by screening and selection in the segregating generations of crosses (Erskine and Kesavan 1982; Eagleton 1983; Mohamadali and Madalageri, 2004; Kuswanto et al. 2016; identification of disease resistant genotypes (Thompson and Haryono 1979); and genomic sequencing studies (Mukhopadhyay 2000; Sharma et al. 1996).

Plant breeding research on winged bean has been ongoing since the 1970-80's era, but it has to be admitted that there have been few developments that have resulted in significant improvements in winged been productivity, and the way it is grown and utilized for human consumption. The research task in Indonesia today is for plant breeders to develop superior cultivars of winged bean that combine high productivity of vegetable pods with high nutritional value under relatively low input conditions; the kind of variety that would assist traditional horticulturists produce winged bean not only for their own needs but also enable them to benefit from expanding urban market opportunities

Genetic diversity within a population is a prerequisite for a successful plant breeding program (Borojevic 1990). Adequate genetic diversity provides opportunities for adaptive genotypic responses to environmental change. The results of research on clover (Trifolium subterraneum L.) show that there was a correlation between several agromorphological characters with environmental variables. These can be considered highly adaptive to environmental pressures (Abdi et al. 2020). Furthermore, it provides opportunity for plant breeders to manipulate the gene pool to generate new genotypes expressing desired combinations of traits. Germplasm evaluation studies over many years have recorded morphological variations in a wide range of characters including in leaves, flowers, pods, seeds, stems and tubers (Khan 1975; Erskine and Kesavan 1982; Mohamadali and Madalageri 2004; Fatihah et al. 2012; Mohanty et al. 2013; Handayani et al. 2015).

Principal component analysis, as applied to data obtained from the measurement of a number of observable characteristics on a large collection of plant accessions, is a technique used for objectively reducing the dimensionality of the dataset to a limited number of uncorrelated, new variables. It can be used to identify those particular characteristics that contribute most to the total observed variation within the collection of evaluated accessions. The output from cluster analysis consists of coefficients of similarity or dissimilarity used to measure overall distance between accessions and between identified groups of accessions. Genetic distance information derived from the analysis can be used in decision-making about which accessions to include as parent lines in on-going plant breeding programs. Accessions with a wide distance between them, if included in a breeding program, expand the selection options available for developing new cultivars.

There have been few studies on the genetic diversity of Indonesian winged bean, and none that have attempted to estimate the genetic distance between accessions in germplasm collections.. The aim of this study is to glean information on genetic variation and distance between the accessions as a preliminary step in the selection of parents for the eventual development of new productive winged bean cultivars.

\section{MATERIALS AND METHOD}

\section{Study area}

The experiment was carried out between November 2017 and June 2018 in Dadaprejo Village, Junrejo District, Batu City, East Java Province. The field site was located at an altitude of $600 \mathrm{~m}$ asl., at longitude 112.572947E and latitude $-7.908635 \mathrm{~S}$ and. The daily temperature at the site ranged between $17^{\circ} \mathrm{C}$ and $30.8^{\circ} \mathrm{C}$. The average humidity ranged from $62 \%$ to $94 \%$ (BMKG 2018).

\section{Materials}

The 21 winged beans (Psophocarpus tetragonolobus) lines evaluated in the study (Table 1) derived from a collection of accessions assembled from five provinces of Indonesia (Bengkulu; Central Java; East Java; West Nusa Tenggara; and Southeast Sulawesi). Nineteen of the winged bean accessions originated from farmers and/or communities who plant winged bean in small amounts as a backyard garden crop or in fringing hedges around fields or household compounds. These accessions underwent preliminary screening and selection to identify lines with interesting, potentially useful characteristics indicative of possible underlying genotypic differences (Table 1). Seed from these was multiplied by line-breeding to form 19 of the lines evaluated in this study. The other two lines (UB1.1 and UB 1.2) included in this study came from a collection held in the Faculty of Agriculture at Universitas Brawijaya. Thus the 21 lines evaluated in the study were a sampling of Indonesian winged bean germplasm with wide potential for genotypic variation.

\section{Method}

The research method used a randomized block design to evaluate the 21 winged bean lines in three replicate blocks. Each block was $3.6 \mathrm{~m}$ x $27 \mathrm{~m}$. Individual plots consisted of beds $1 \mathrm{~m}$ wide by $3.6 \mathrm{~m}$ in length with an intended plant spacing within the beds of $0.6 \mathrm{~m} \times 1 \mathrm{~m}$. Each plant was provided by thick bamboo poles that are separated from other plants. Bamboo poles height of about $2 \mathrm{~m}$, consisting of three bamboos and tied at the top. To foster germination, seeds were scarified using sandpaper to abrade the back of the seeds and then soaked in warm water for 24 hours. The 21 seed batches were then sown into trays containing a 1:1 mixture of soil and manure, and grown in the trays for two weeks before planting out into the field at the two trifoliate leaf stage. The field planting was carried out in the afternoon. Each bed plot consisted of six planting holes with each planting hole filled by a single winged bean seedling. Re-planting has carried out for two weeks to gapfill any missing planting points. Fertilization was conducted on three occasions: (i) one week after planting (7 DAP), (ii) during flowering, and (iii) during pod formation. At 7 days after planting, the fertilizer applied 
was Urea $14 \mathrm{~g}$, SP36 (superphosphate containing 36\% $\left.\mathrm{P}_{2} \mathrm{O}_{5}\right) 20 \mathrm{~g}$; and $\mathrm{KCl} 14 \mathrm{~g}$ per plant. At the flowering stage, the dosage of fertilizer was Urea10 g, SP36 $15 \mathrm{~g}$, and $\mathrm{KCl}$ $10 \mathrm{~g}$ per plant. During pod formation, NPK fertilizer (15: 15: 15) was applied at a rate of $10 \mathrm{~g}$ per plant. Irrigation was carried out (by opening a water channel once a week) only when there was no rain. Pests and plant diseases were controlled mechanically if the intensity was low, and using pesticides if the pest attack was moderate to severe.

Observations were made on both quantitative and qualitative characters.

The observed quantitative characters were: (i) days to first flowering (i.e. the number of days from planting to the date when the first open flower appeared in the plant); (ii) days to first green pod harvest (i.e. the number of days from planting until the date when the vegetable pods in a plant were judged to first reach harvestable stage); (iii) pod length based on the mean of ten pods per plant; (iv) pod width, based on the mean of ten pods per plant; (v) the weight of a pod, based on the mean of ten pods per plant; (vi) total number of pods per plant, calculated from the first to the 10th harvest; (vii) total weight of pods per plant; calculated from the number of pods multiplied by the weight of pod; (viii) mean number of seeds per pod; calculated from a random sample of ten pods. The samples used for in measurement were three plants in each replicate plot.

The observed qualitative characters were twelve in number, namely: stem color; leaflet shape; pod color; pod wing color; pod surface texture; pod shape; presence of pod specks; the anthocyanin color intensity in pods; calyx color; corolla color; seed color; and seed shape (see Table 2 ). These observations on qualitative characters were carried out using the IBPGR (1982) descriptor list for winged bean. In Indonesia, this descriptor list has been published as a modified Test Implementation Guide (PPU) to ensure uniqueness, uniformity, and stability in describing plant characteristics (PVTPP 2014).

\section{Data analysis}

For each qualitative character, the number of lines (n) expressing a particular trait as listed in Table 2 was converted into a percentage ( $\mathrm{n} \times 100 / 21)$.

For quantitative characters, mean plot values were used as input to calculate the minimum, maximum, mean, standard deviation, and coefficient of variation for each line across its three replicate blocks, using the $19^{\text {th }}$ edition of the Genstat software package. In addition, the XLSTAT version 2014 software package was used to construct boxplots for each quantitative character that illustrated in graphical terms the minimum, $1^{\text {st }}$ quartile, median, third quartile, and maximum values across the 21 lines.

Table 1. The origins of the twenty-one winged bean lines evaluated in this study

\begin{tabular}{ll}
\hline $\begin{array}{l}\text { Winged bean } \\
\text { lines }\end{array}$ & Origin \\
\hline SKB 1.5 & Bengkulu, West Sumatra \\
PLB 1.1 & Brebes, Central Java \\
PLB 2.3 & Brebes, Central Java \\
KPN 3.2.1 & Nganjuk, East Java \\
BNN 1.1 & Nganjuk, East Java \\
MNN 1.1 & Nganjuk, East Java \\
NSM 2.1 & Malang, East Java \\
CKM 1.1.1 & Malang, East Java \\
KePM 1.2.3 & Malang, East Java \\
SWM 1.1 & Malang, East Java \\
KaPM 2.1 & Malang, East Java \\
MDM 1.2 & Malang, East Java \\
KePM 2.5 & Malang, East Java \\
KePM 2.2 & Malang, East Java \\
DJB 1 & Batu, East Java \\
DJB 2 & Batu, East Java \\
KPJ 1.1.1 & Jember, East Java \\
PTL 2.1 & Lombok Utara, West Nusa Tenggara \\
MML 1.4 & Luwu Timur, Southeast Sulawesi \\
UB 1.1 & Plant Breeding Laboratory Collection, Faculty of \\
& Agriculture, Univ. Brawijaya, Malang, East Java \\
UB 1.2 & Plant Breeding Laboratory Collection, Faculty of \\
& Agriculture, Univ. Brawijaya, Malang, East Java \\
\hline
\end{tabular}

Table 2. List of observed qualitative characters based on the terminology of the modified (IBPGR 1982) descriptor list incorporated in PVTPP (2014).

\begin{tabular}{ll}
\hline Characters & Expression \\
\hline Stem color & Green (1), Greenish purple (2), Purple (3), Other (4) \\
Leaflet shape & Ovate (1), Deltoid (2), Ovate lanceolate (3), Lanceolate (4), Long lanceolate (5) \\
Pod color & Cream (1), Green (2), Pink (3), Purple (4), Other (5) \\
Color of wing pods & Green (1), Purple (2), Other (3) \\
Pod surface texture & Smooth (3), Medium (5), Rough (7) \\
Pod shape & Rectangular (1), Semiflat (2), Flat on side (3), Flat on suture (4) \\
Presence of pod specks & Absent (1), Present (9) \\
Anthocyanin color intensity in pods* & None (1), Weak (3), Medium (5), Strong (7), Very strong (9) \\
Corolla color & White (1), Blue (2), Purplish blue (3), Purple (4), Reddish purple (5) \\
Calyx color & Green (1), Greenish purple (2), Purple (3), Other (4) \\
Seed color & Cream (1), Light Brown (2), Brown (3), Purple (4), Black (5), Brown-black (6), \\
& Purplish black (7), White (8). \\
Seed shape & Round (1), Oval (2), Oblong (3) \\
\hline Note: * indicates additional characters not listed in Descriptors for winged bean (IBPGR 1982) and PVTPP (2014)
\end{tabular}


A multivariate analysis was then carried out on the data set, employing the Multivariate Statistical Program (MVSP) software package version 3.1. The matrix of pairwise Pearson's correlation coefficients between the eight quantitative variables across the 21 lines provided the input into a principal component analysis (PCA). The PCA was used to determine to what extent each of the eight variables contributed to the total measured variation among the eight variables measured on the 21 lines. Of the eight orthogonal components generated by the analysis, only three components with an eigenvalue $>1$ were accepted as accounting for significant proportion of the total variation (Mattjik and Sumertajaya 2011). On these three principal components, a character was considered as making a significant contribution if its loading coefficient $\geq 0.6$, (Peres-Neto et al. 2003). The combined data set was then subjected to a cluster analysis using an agglomerative hierarchical clustering procedure applied to Euclidean distance and a UPGMA (Unweighted Pair Group Method Using Arithmetic Average) strategy to group the 21 lines and to represent these groupings in the form of dendrograms (Mohammadi and Prasanna 2003)

\section{RESULTS AND DISCUSSION}

\section{Observations on qualitative characters}

Investigations of the genetic variation within underutilized crop species are indispensable to planning useful breeding strategies to improve them (Cooper et al. 2001). In addition, comprehensive characterization provides a foundation for efficient germplasm conservation that enables future genetic improvement (Fitriana and Susandarini 2019).

Genetically based phenotypic variation in winged bean in Indonesia has been observed among local collections of accessions from several regions. A previous investigation characterized several local accessions of Indonesian winged bean and documented observed variation in several morphological characters e.g. corolla color, appearance of anthocyanin in pods, pod length, and days to first flowering (Permatasari et al. 2018).

In the present study, morphological observations were conducted on 12 qualitative and 8 quantitative characters among 21 Indonesian winged bean lines. The results are summarised in Table 3 for the qualitative characters and in Table 4 for the quantitative characters.

Among the qualitative characters, stem color was predominantly green (19 lines i.e. $90.47 \%$ ) while greenishpurple and purple colors respectively were observed in just one line each (i.e. $4.76 \%$ each). This result is similar to that of Khan (1976) in Papua New Guinea who observed that the basic colors of winged bean stem were either green or purple, with green being the most common. The intensity of purple on the stem in our study varied from purple tinge with green-base to purple. Leaflet shapes were of three types (deltoid $85.71 \%$, ovate-lanceolate $4.76 \%$, and long lanceolate $9.52 \%$ ). Three pod shapes were found (rectangular $61.90 \%$, semi-flat $33.33 \%$, and flat on the side
4.76\%). Pod shape was observed by cross-cutting the pods. Pod surface texture was of two types (smooth $33.33 \%$ and medium $66.67 \%$ ). Pod color was all green $(100 \%)$. The pod wing color had two types ( green $90.48 \%$, and purple 9.52\%). The pods had three basic colors i.e. green, pink, and pale yellow. On green pods, purple specks with various degrees of color intensity were observed, to the point that some pods could be considered as uniformly purple in color (Khan 1976). Pods without any anthocyanin were the most common $(90.47 \%)$ while pods with anthocyanin were found in only two lines $(9.52 \%)$. Of these two lines, one had pods with weak anthocyanin color intensity (4.76\%) while the other line had a moderate anthocyanin color intensity $(4.76 \%)$ (Figure 1). The pod wing color was generally green with variant variation from light purple to dark purple (Khan 1976). There were four corolla colors: blue $(28.57 \%)$, purplish-blue $(57.14 \%)$, purple $(9.52 \%)$, and reddish-purple $(4.76 \%)$ (Figure 2$)$. The corolla basecolor was purple and blue in which blue was more typically found than purple. In some cases, there were white and bright blue colors. The most common calyx color was green $(85.71 \%)$, while two lines $(9.52 \%)$ had greenishpurple calyces, and one line $(4.76 \%)$ had dark purple calyces. Seed color also varied, namely light brown $(9.52 \%)$, brown $(80.95 \%)$, and black $(9.52 \%)$. Seed shape was predominantly round (18 lines; $85.71 \%)$, while three lines had oval-shaped seed (14.29\%).

In this study, purple coloration was found in several of our defined characters: calyx color; corolla color; pod specks; pod wing color; and anthocyanin intensity in pods. Some lines had purple or reddish-purple corollas, while the calyx color appeared dark purple. Thompson and Haryono (1980), in their study in Central Java of Indonesian winged bean germplasm, found evidence that dark purple corolla color was related to pigmentation in the calyx, pod specks, and the pod wings. In Papua New Guinea germplasm, Erskine and Khan (1977) carried out genetic analysis of five qualitative characters finding each of them to be strongly influenced by singe gene loci; purple stem color was found to be completely dominant over green stem color, purple calyx over green calyx, purple over green pod wing color, purple specks over uniformly green pod color, and rectangular pod shape over flat pod shape.

Furthermore, significant genetic linkage was observed between stem color and calyx color and between wing color and pod specking. In the present study, it was found that there was a correspondence between purple or reddishpurple corolla and the appearance in pods of anthocyanin with weak to moderate intensity, and with purple color in the wings of pods. Two lines that had those character traits were KePM 2.2 and MDM 1.2. It needs to be emphasized that the phenotypic expression of a simple inherited character may differ depending on the genetic background within the particular population in which the character is observed. Even so, qualitative characters such as stem color, leaflet shape, calyx/corolla color, pod shape, and pod surface texture have proved to be very useful, relatively stable, markers for genetic studies (Erskine and Khan 1977). 


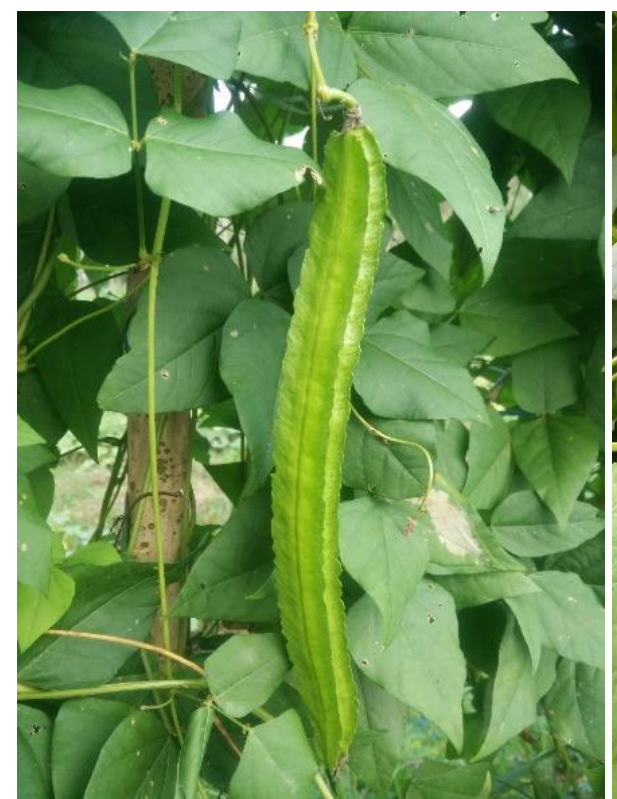

A

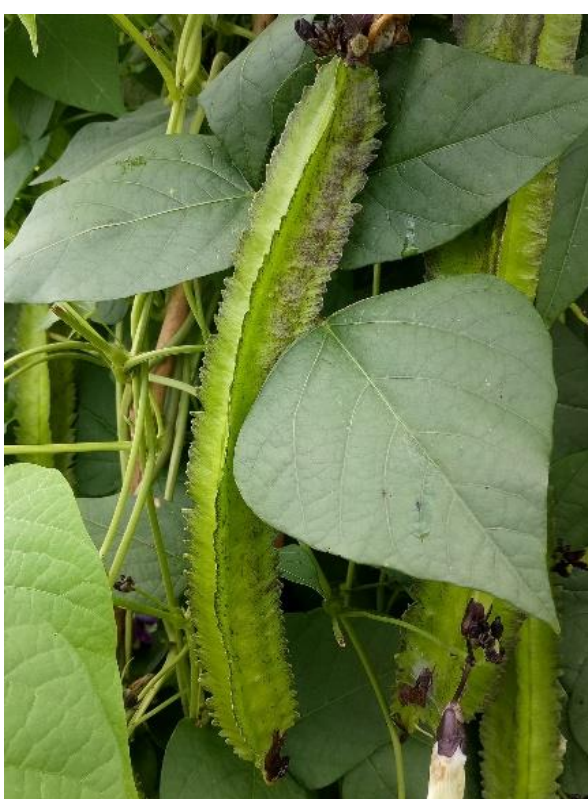

B

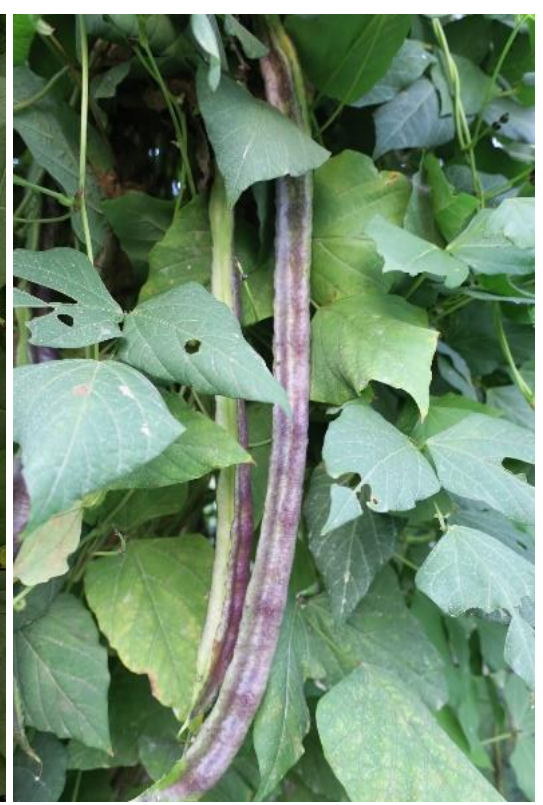

C

Figure 1. Anthocyanin color intensity of winged bean pods. A. None; B. Weak; C. Moderate

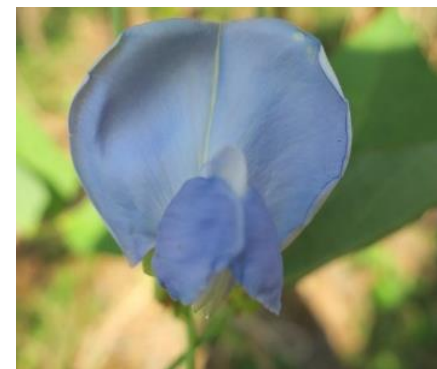

$\mathbf{A}$

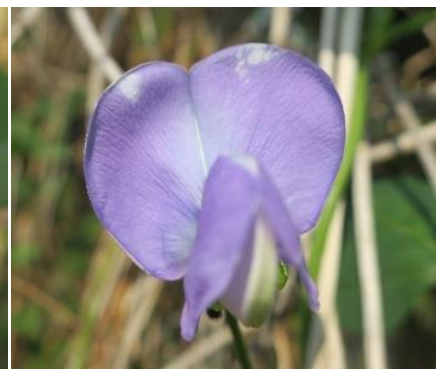

B

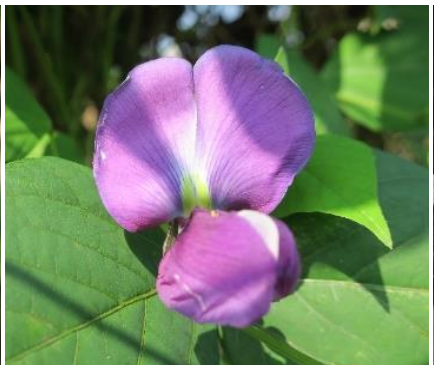

C

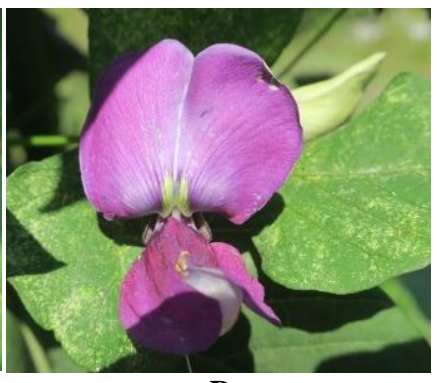

D

Figure 2. Color variations of the corollas. A. Blue; B. Purplish blue; C. Purple; D. Reddish purple

\section{Observations on quantitative characters}

The results of observations on eight quantitative characters measured on the 21 winged bean lines are presented in Table 4, in which the values for the minimum, maximum, mean, and coefficient of variation for each quantitative character are listed.

On average, the 21 lines took 68 days from the time of planting to reach the first open flower stage. The line PTL 2.1 was the quickest to flower (58 days) while KPJ 1.1 was the slowest ( 81 days). The average time from planting to first harvestable green pods was 123 days with MML1.4 b being the fastest (99 days) and SKB 1.5 the slowest (151 days). The long time required by winged bean, with its viny plant architecture, to reach flowering and pod maturity has been reported in many studies (Eagleton 2019; Tanzi et al. 2019). Daylength and temperature have significant influences on growth and phenology of winged bean (Schiavianto and Valio 1996). Some Indonesian accessions adapted to high rainfall and luxuriant growing conditions such as those that occur in Bogor, West Java, have a particularly extended vegetative growth phase before they reach flowering, followed by a long reproductive phase (Eagleton 2019). On the other hand, Erskine (1981) reported Papua New Guinea accessions that reached first open flower in as few as 44 days. In our study, we identified Indonesian lines in which the number of days to first flower was as short as 58 days, compared with the study in Bogor in which no flowering occurred in under 70 days.

Tanzi et al. (2019) have suggested that the interaction between morphology, growth, and yield is a potential target in breeding programs aimed at developing productive winged bean ideotypes. In this study, the line with shortest pod length $(13.7 \mathrm{~cm})$, line PLB 1.1 also had the lowest pod weight, $8.05 \mathrm{~g} /$ pod. while the line with the longest pods $(38.4 \mathrm{~cm})$, line NSM 2.1 also had the highest pod weight 
(25.65 g/pod). The average number of pods per plant among the 21 lines ranged from 29 in line DJB 1 to 55 in line SWM 1.1. The total pod weight per plant among the 21 lines ranged from $372.7 \mathrm{~g}$ to $1169.5 \mathrm{~g}$, with an overall mean of $673.1 \mathrm{~g}$. The number of seeds per pod ranged from 11 in line PLB 1.1 to 18 in line NSM 2.1, with an average of 14.2 per pod across all 21 lines. For the character pod length, the variation across the 21 winged bean lines appeared to fall into three natural groupings, lines with short pods $(8.0 \mathrm{~cm}-15.0 \mathrm{~cm})$, those with moderate pod length $(15.1 \mathrm{~cm}-24.0 \mathrm{~cm})$, and those with long pods $(>24.1 \mathrm{~cm})$. Genotype NSM 2.1, with long pods $(>30 \mathrm{~cm})$ and high number of seed per pod $(>15)$ produced the greatest weight of pods per plant $(>1000 \mathrm{~g})$. Kuswanto et al. (2016) have suggested that pod length is a pivotal character in the selection and improvement of winged bean varieties despite its higher yield, the long pods of NSM 2.1 are irregular in shape, thus lowering its aesthetic appeal as a vegetable variety. Careful consideration will need to be given to various pod characteristics in developing vegetable ideotypes for winged bean.

In planning plant breeding programs, a critical issue is an extent to which phenotypic variability in characteristics is a reflection of underlying genotypic variability, and thus is exploitable in genetic terms. One indicator of this underlying genotypic variability, in a germplasm evaluation of the kind undertaken in this study, is the coefficients of variation for the characters assessed (Table 4). Another is the evenness of distribution of this variation across the range for each character best expressed graphically in the form of box plots. Figure 3 presents boxplot graphs for each of the eight quantitative characters, in which the spread of values for each character is depicted in terms of the first quartile, median and third quartile values.

Coefficients of variation (CV) for the two characters number of days to first open flower and for pod width were less than $10 \%$. For number of days to first harvestable green pods, for number of pods per plant, and for number of seed per pod, the CV lay between $13.9 \%$ and $20.7 \%$; while for pod length, pod weight, and pod weight per plant CV exceeded $25 \%$.

The box plot analyses give an indication not only of the spread but also the skew in the distribution of the 21 line means for each character. For number of days to first open flower, for pod length, and for individual pod weight, there were more lines with values below the overall mean than above it. On the other hand, for number of days to first harvestable green pods and for number of pods per plant there were more lines above the mean than below it. Extreme values, such as in pod length for line NSM 2.1, are a cause of skewness, and draw attention to possible exploitable genetic variants.

Table 3. Variations in 12 qualitative characters based on the modified Psophocarpus tetragonolobus descriptor list (PVTPP 2014, derived from IBPGR 1982).

\begin{tabular}{|c|c|c|c|}
\hline Characters & Description & $\begin{array}{l}\text { No. of } \\
\text { lines }\end{array}$ & $\begin{array}{l}\text { \% of } \\
\text { lines }\end{array}$ \\
\hline \multirow{3}{*}{ Stem color } & Green & 19 & 90.47 \\
\hline & Greenish purple & 1 & 4.76 \\
\hline & Purple & 1 & 4.76 \\
\hline \multirow[t]{3}{*}{ Leaflet shape } & Deltoid & 18 & 85.71 \\
\hline & Ovate lanceolate & 1 & 4.76 \\
\hline & Long lanceolate & 2 & 9.52 \\
\hline Pod color & Green & 21 & 100.00 \\
\hline \multirow{2}{*}{ Color of wing pods } & Green & 19 & 90.48 \\
\hline & Purple & 2 & 9.52 \\
\hline \multirow[t]{2}{*}{ Pod surface texture } & Smooth & 7 & 33.33 \\
\hline & Medium & 14 & 66.67 \\
\hline \multirow[t]{3}{*}{ Pod shape } & Rectangular & 13 & 61.90 \\
\hline & Semiflat & 7 & 33.33 \\
\hline & Flat on side & 1 & 4.76 \\
\hline \multirow{2}{*}{$\begin{array}{l}\text { Presence of pod } \\
\text { specks }\end{array}$} & Absent & 19 & 90.47 \\
\hline & Present & 2 & 9.52 \\
\hline Anthocyanin color & None & 19 & 90.47 \\
\hline \multirow{2}{*}{ intensity in pods } & Weak & 1 & 4.76 \\
\hline & Medium & 1 & 4.76 \\
\hline \multirow[t]{4}{*}{ Corolla color } & Blue & 6 & 28.57 \\
\hline & Purplish blue & 12 & 57.14 \\
\hline & Purple & 2 & 9.52 \\
\hline & Reddish purple & 1 & 4.76 \\
\hline \multirow{3}{*}{ Calyx color } & Green & 18 & 85.71 \\
\hline & Greenish purple & 2 & 9.52 \\
\hline & Dark purple & $\mathrm{i}$ & 4.76 \\
\hline \multirow[t]{3}{*}{ Seed color } & Light brown & 2 & 9.52 \\
\hline & Brown & 17 & 80.95 \\
\hline & Black & 2 & 9.52 \\
\hline \multirow[t]{2}{*}{ Seed shape } & Round & 18 & 85.71 \\
\hline & Oval & 3 & 14.29 \\
\hline
\end{tabular}

Table 4. Minimum, maximum, mean, and coefficient of variation for eight quantitative characters of 21 winged bean (Psophocarpus tetragonolobus) lines.

\begin{tabular}{|c|c|c|c|c|c|c|c|}
\hline Characters & Code & Min. & Lines & Max. & Lines & Mean & $\mathrm{CV}(\%)$ \\
\hline Days to first open flowers & DFF & 58 & PTL 2.1 & 81 & KPJ 1.1 & 68 & 9.5 \\
\hline Days to first harvestable green pods & DHGP & 99 & MML 1.4 & 151 & SKB 1.5 & 123 & 14.1 \\
\hline Pod length $(\mathrm{cm})$ & PL & 13.7 & PLB 1.1 & 38.4 & NSM 2.1 & 22.6 & 27.8 \\
\hline Pod width (cm) & PW & 1.30 & KPN 3.2.1 & 1.97 & BNN 1.1 & 1.47 & 9.6 \\
\hline Individual pod weight $(\mathrm{g})$ & IPW & 8.05 & PLB 1.1 & 25.65 & NSM 2.1 & 16.09 & 20.7 \\
\hline Number of pods per plant & NPP & 29 & DJB 1 & 55 & SWM 1.1 & 43 & 32.1 \\
\hline Total weight of pods per plant $(\mathrm{g})$ & TWPP & 372.7 & UB 1.1 & 1169.5 & NSM 2.1 & 673.1 & 33.4 \\
\hline Number of seeds per pod & NSP & 11.1 & PLB 1.1 & 17.6 & NSM 2.1 & 14.2 & 13.9 \\
\hline
\end{tabular}




\section{Principal components analysis}

The results of a principal components analysis (PCA) applied to the quantitative characters, are presented in Table 5. Three components with eigenvalues $>1$, accounting in total for $85.57 \%$ of the data on the original eight characters, were considered adequate to describe the data and to allow for useful inferences about the structure of the complete data. Component 1 , with an eigenvalue of 3.917 , accounted for $48.97 \%$ of the variation in the original data set. Component 2 with an eigenvalue of 1.574 , accounted for an additional $19.67 \%$ of the original variability, and component 3 accounted for another $16.9 \%$. Several characters were closely aligned on component 1 . These were days to first open flower and days to first harvestable green pod, along with pod length, pod weight, number of seeds per pod and the total weight of pods per plant. On the other hand, the two characters number of pods per plant and pod width, contributed significantly only to component 3 , and their contribution was in opposite directions.

According to Afuape et al. (2011), principal component analysis is a technique useful for identifying plant characters that contribute the most to the observed variation in genotypic groups. It has practical applications in exploring germplasm for the identification of parents for possible inclusion in breeding purposes and for inferring hypotheses about the contribution that individual characters might be expected to make to breeding objectives. The results of our principal components analysis appear to be in general agreement with those of Erskine and Kesavan (1982) who found a strong heritable correlation between pod length and pod weight, but little relationship of these variables with pod number per plant. The results also suggest that the quest for an early flowering winged bean genotype might be associated with a lower accumulative vegetable pod yield within the Javanese environment (Eagleton 2019).

\section{Cluster analysis of winged bean lines}

The cluster analysis of multivariate dissimilarity measures between the 21 winged bean lines based on observations of the 12 qualitative characters is shown in Figure 4 in the form of a dendrogram, with Euclidean dissimilarity coefficients ranging from 0 to 9.46. Low dissimilarity coefficients indicate close relationships among lines, and between clusters of lines. Eight lines had dissimilarity coefficients of 0 between them i.e. KaPM 2.1, MML 1.4, KPN 3.2.1, UB 1.2, KPJ 1.1. 1, KePM 1.2.3, BNN 1.1, SKB 1.5. This indicated they were identical in terms of the observed set of qualitative characters. Besides those eight lines, the two lines (PLB 1.1 and PLB 2.3) had a dissimilarity coefficient of 0 between them. The lines PLB 1.1 and PLB 2.3, both originated from Brebes, Central Java.

In the dendrogram in Figure 4, a Euclidean dissimilarity coefficient of 4.8 was used as a reference point in identifying two main clusters among the 21 lines based on qualitative characters. The similarity of characters in lines in clusters and the distinguishing of character between clusters in Table 6.
DFF
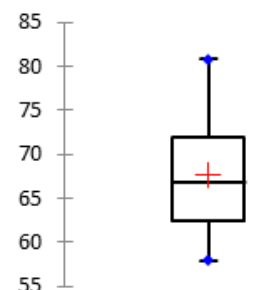

IPW

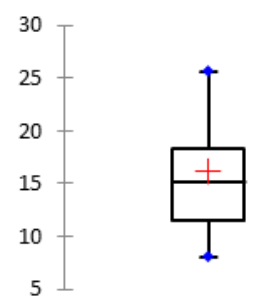

DHGP

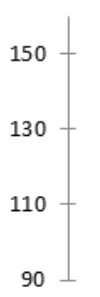

NPP

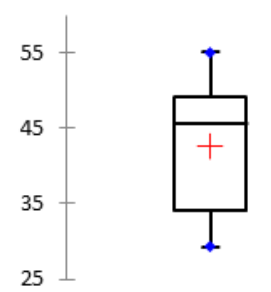

PL
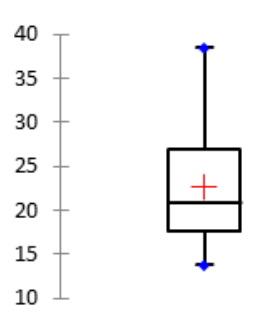

TWPP

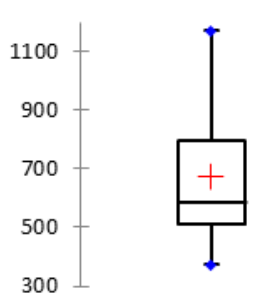

PW

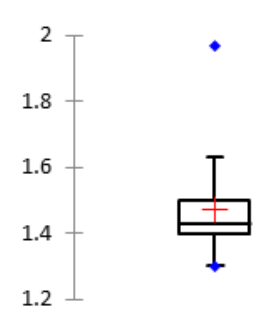

NSP

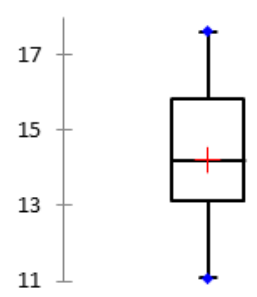

Figure 3. Boxplots of eight quantitative characters measured across 21 winged bean lines: DFF: days to first Flower; DHGP: days to first harvestable green pods; PL: pod length $(\mathrm{cm})$; PW: pod width $(\mathrm{cm})$; IPW: individual pod weight $(\mathrm{g})$; NPP: number of pods per plant; TWPP: total weight of pods per plant (g); NSP: number of seeds per pod. In the box plot, the cross, is the mean value, the blue dots are the minimum and maximum values, the lower edge of the box is the first quartile value, the central line is the median value, and the upper edge of the box is the third quartile. The whiskers are the Tukey limits (lower and upper respectively) 
Table 5. The coefficients of loading of quantitative character on the three principal components as the result of PCA

\begin{tabular}{llll}
\hline Characters & PC1 & PC2 & PC3 \\
\hline Days to first flowering & $\mathbf{0 . 7 2 8}$ & -0.565 & 0.233 \\
Days to green pod harvesting & $\mathbf{0 . 6 8 4}$ & -0.606 & 0.137 \\
Pod length & $\mathbf{0 . 8 2 7}$ & 0.352 & -0.329 \\
Pod width & -0.381 & 0.290 & $\mathbf{- 0 . 6 4 4}$ \\
Weight per pod & $\mathbf{0 . 9 1 7}$ & 0.265 & -0.156 \\
Number of pod per plant & -0.277 & 0.529 & $\mathbf{0 . 7 5 7}$ \\
Weight of pods per plant & $\mathbf{0 . 7 3 5}$ & 0.541 & 0.356 \\
Seed per pod & $\mathbf{0 . 7 9 5}$ & 0.191 & -0.182 \\
& & & \\
Eigenvalue & 3.917 & 1.574 & 1.354 \\
Variance $(\%)$ & 48.970 & 19.670 & 16.930 \\
Cumulative $(\%)$ & & & 85.570 \\
\hline
\end{tabular}

\section{Appropriate breeding methods based on genetic variation and distance}

Hybridization between distinctive genotypes followed by judicious selection in the segregating generations is a classical plant breeding method. If the prospective parent genotypes are very different from one another then it is to be expected that there will be a high level of genetic variation among the segregating generations that ensue from a cross between them. In our study, the evaluation of qualitative and quantitative characters on the 21 lines was an important step in determining the genetic diversity among our collection of Indonesian winged bean germplasm and in identifying potential parents for breeding improved cultivars.

Table 6. The similarity of characters in clusters and the distinguishing character between clusters

\begin{tabular}{lllll}
\hline $\begin{array}{c}\text { The similarity of } \\
\text { character in cluster 1 }\end{array}$ & $\begin{array}{c}\text { Lines in } \\
\text { cluster 1 }\end{array}$ & $\begin{array}{c}\text { The similarity of } \\
\text { character in cluster } \\
\mathbf{2}\end{array}$ & \multicolumn{1}{c}{ Lines in cluster 2 } & $\begin{array}{c}\text { The distinguishing of character } \\
\text { between clusters }\end{array}$ \\
\hline Green stem color & MDM 1.2 & Green pod color & NSM 2.1, CKM 1.1, MNN & Pod wing color \\
Deltoid leaflet shape & KePM 2.2 & Green pod wing color & 1.1, PLB 2.3, PLB 1.1, SKB & $\begin{array}{l}\text { Presence of pod specks } \\
\text { Green pod color }\end{array}$ \\
& & Absence of pod specks & 1.5, & Anthocyanin color intensity in pods \\
Purple pod wing color & & & BNN 1.1, KePM 1.2, KPJ & Seed color \\
Presence of pod specks & & & 1.1 .1$, UB 1.2, KPN 3.2.1, & \\
Black seed color & & MML 1.4, KaPM 2.1, KePM & \\
& & & SWM 1.1, DJB 1, & \\
& & & UB 1.1 & \\
\hline
\end{tabular}

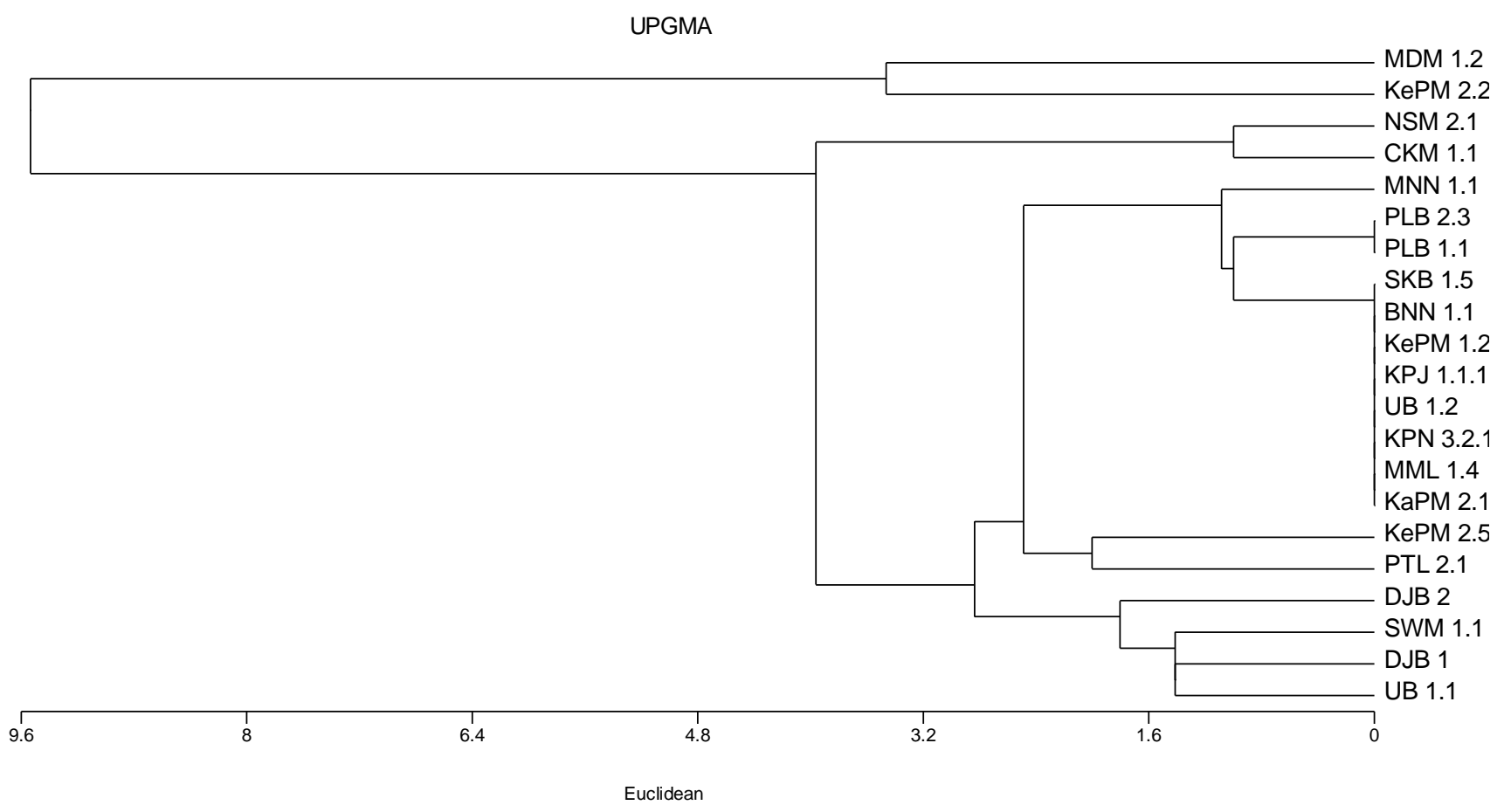

Figure 4. Genetic dendrogram of 21 winged bean genotypes analyzed by Unweighted pair group method (UPGMA) based on 12 qualitative characters 
Differences in qualitative characteristics in clusters of lines are useful as markers in validating the effectiveness of crosses in a breeding program. In some cases, a particular qualitative characteristic may be linked as a marker to desired characteristics in a commercial cultivar. In other cases, particular qualitative characteristics or combinations of characteristics may be desired in their own right. Thus, for example, the genotype MDM 1.2 could be used as a candidate for introducing anthocyanin color with moderate color intensity, in order to generate novel, purple-winged pods into cultivars. Among the quantitative characters in our study, pod length and weight had high coefficients of variation, with line NSM 2.1 having an exceptional pod length of $38.4 \mathrm{~cm}$ (Table 4). Genetic analysis, involving crosses between lines like NSM 2.1 and MDM 1.2, followed by evaluation in F1, F2 and perhaps backcross generations, would help to elucidate the extent to which pod length and anthocyanin color are under genetic control and what influence they have on important productive parameters such as total yield of vegetable pods (Erskine and Kesavan 1982).

\section{ACKNOWLEDGEMENTS}

The author would like to thank LPDP (Indonesian Endowment Fund for Education) for the granting of a 2016 Indonesian domestic lecturer scholarship (BUDI DN) which funded doctoral study research.

\section{REFERENCES}

Abdi AI, Nichols PGH, Kaur P, Wintle BJ, Erskine W. 2020 Morphological diversity within a core collection of subterranean clover (Trifolium subterraneum L.): Lessons in pasture adaptation from the wild. PLoS One. 15(1):1-26.

Afuape SO, Okocha PI, Njoku D. 2011. Multivariate assessment of the agromorphological variability and yield components among sweetpotato (Ipomoea batatas ( L .) Lam) landraces. Afr J Plant Sci 5 (2): 123-132.

BMKG. 2018. Data iklim harian. Badan Meteorologi Klimatologi dan Geofisika. http//dataonline.bmkg.go.id/akses data.

Borojevic S. 1990. Principles and Methods of Plant Breeding. Elsevier Science Publishers B.V., Netherlands.

Cooper HD, Spillane C, Hodgkin T. 2001. Broadening the genetic base of crops an Overview. In: Cooper H, Spillane C, Hodgkin T, editors. Broadening Genetic Base of Crop Production. CABI Publishing, London.

Eagleton G, Halim A, Chai N. 1980. Towards the effective utilisation of winged bean germplasm. In: Proceeding of Legumes in the Tropics. Universiti Pertanian Malaysia, Selangor, Malaysia.

Eagleton GE. 1983. Evaluation of genetic resources in the winged bean (Psophocarpus tetragonolobus (L.) DC.) and their utilisation in the development of cultivars for higher latitudes. [Dissertation]. Institute of Agriculture, University of Western Australia, Perth.

Eagleton GE. 2019. Prospects for developing an early maturing variety of winged bean (Psophocarpus tetragonolobus) in Bogor, Indonesia. Biodiversitas. 20 (11): 3142-3152.

Erskine W, Kesavan V. 1982. Genetic variability in the green pod production of winged bean. J Hortic Sci 57 (2): 209-213.

Erskine W, Khan TN. 1977. Inheritance of pigmentation and pod shape in winged bean. Euphytica 26 (3): 829-831.

Erskine W. 1980. Measurement of the cross-pollination of winged bean in Papua New Guinea. Sabrao J 12 (1): 11-14.
Erskine W. 1981. Heritability and combining ability of vegetative and phenological characters of winged beans (Psophocarpus tetragonolobus (L) DC.). J Agric Sci 96: 503-508.

Fatihah HNN, Maxted N, Rico Arce L. 2012. Cladistic analysis of Psophocarpus Neck. ex DC. (Leguminosae, Papilionoideae) based on morphological characters. S A J Bot 83: 78-88.

Fitriana N, Susandarini R. 2019. Morphology and taxonomic relationships of shallot (Allium cepa L. group aggregatum) cultivars from Indonesia. Biodiversitas 20 (10): 2809-2814.

Handayani T. 2013. Kecipir (Psophocarpus tetragonolobus L .), Potensi Lokal yang Terpinggirkan. IPTEK Tanaman Sayuran 1: 1-8. [Indonesian]

Handayani, Kusmana T, Liferdi, Hidayat I. 2015. Karakterisasi Morfologi dan Evaluasi Daya Hasil Sayuran Polong Kecipir (Psophocarpus tetragonolobus (L.) DC). Jurnal Hortikultura 25 (2): 126-132. [Indonesian]

IBPGR. 1982. Revised Winged Bean Descriptors. Southeast Asia Regional Committee of International Board for Plant Genetic Resources. FAO, Rome, Italy.

Khan TN. 1975. Variation in winged bean in Papua New Guinea. South East Asian Genetic Resources. Lembaga Biologi Nasional LIPI. Bogor.

Khan TN. 1976. Papua New Guinea : A centre genetic diversity in winged bean (Psophocarpus tetragonolobus (L.) DC). Euphytica 25: 693706.

Klu GYP, Jacobsen E, Van Harten AM. 1997. Induced mutations in winged bean (Psophocarpus tetragonolobus L. DC) with low tannin content. Euphytica 98: 99-107.

Kuswanto, Ardiarini NR, Saptadi D, Waluyo B. 2016. Evaluation and selection on local strains of winged bean in Brawijaya University Indonesia. In: Osman M, Abdullah S, Muhammad N, Milan A, Sulaiman Z, Rokman Z (eds.). Proceeding Transactions Persatuan Genetic Malaysia 3: 51-55.

Mattjik AA, Sumertajaya IM. 2011. Sidik Peubah Ganda dengan Menggunakan SAS. IPB Press, Bogor. [Indonesian]

Mohamadali A, Madalageri M. 2004. Correlation and path analysis studies for green vegetable pod yield and yield attributes in winged bean (Psophocarpus tetragonolobus (L.) DC). Indian J Hortic. 61 (4): 335-337.

Mohamadali A, Madalageri MB. 2015. Analysis of genetic variability for seed yield and its component characters in winged bean (Psophocarpus Tetragonolobus (L.) Dc). Legum Res Intl J 30 (4): 290-291.

Mohammadi SA, Prasanna BM. 2003. Analysis of genetic diversity in crop plants - salient statistical tools. Crop Sci 43: 1235-1248.

Mohanty CS, Verma S, Singh V, Khan S, Gaur P, Gupta P, Nizar MA, Dikshit N, Pattanayak R, Shukla A, et al. 2013. Characterization of winged bean (Psophocarpus tetragonolobus (L.) DC.) based on molecular, chemical and physiological parameters. Am J Mol Biol 03 (4): 187-197.

Motior MR, Wan Mohamad WO, Wong KC, Shamsuddin ZH. 1998b. Physiological studies of ratooned and non-ratooned winged bean grown with and without support. In: Proceeding $9^{\text {th }}$ Australian Agronomy Conference. Wagga, NSW. http;//www.rwgional.org.au/au/asa/1984/4/214motior.htm

Mukhopadhyay D. 2000. The molecular evolutionary history of a winged bean $\alpha$-chymotrypsin inhibitor and modeling of its mutations through structural analyses. J Mol Evol 50 (3): 214-223.

Peres-Neto PR, Jackson DA, Somers KM. 2003. Giving meaningful interpretation to ordination axes: Assessing loading significance in principal component analysis. Ecology 84 (9): 2347-2363.

Permatasari N., Adiredjo A., Kuswanto. 2018. Evaluasi keragaman dan potensi galur kecipir (Psopocarpus tetragonolobus L .) lokal hasil koleksi. Jurnal Produksi Tanaman 6 (12): 3022-3031. [Indonesian]

PVTPP. 2014. Panduan pelaksanaan uji (PPU) keunikan, keseragaman dan kestabilan kecipir winged bean (Psophocarpus tetragonolobus $\mathrm{L}$ ). Pusat Perlindungan Varietas Tanaman dan Perizinan Pertanian, Kementerian Pertanian, Jakarta [Indonesian].

Schiavianto MA, Valio IFM. 1996. Influence of staking on development of winged bean plants. R Bras Fisiol Veg 8 (2): 99-103.

Sharma V, Srinivas VR, Surolia A. 1996. Cloning and sequencing of winged bean (Psophocarpus tetragonolobus) basic agglutinin (WBA I): Presence of second glycosylation site and its implications in quaternary structure. FEBS Lett. 389 (3): 289-292. 
Tanzi AS, Eagleton GE, Ho WK, Wong QN, Mayes S, Massawe F. 2019. Winged bean (Psophocarpus tetragonolobus (L.) DC.) for food and nutritional security: synthesis of past research and future direction. Planta. 250 (3): 911-931.

Tanzi AS, Ho WK, Massawe F, Mayes S. 2019. Development and interaction between plant architecture and yield-related traits in winged bean (Psophocarpus tetragonolobus (L.) DC.). Euphytica. 215 (2): 36. DOI: 10.1007/s10681-019-2359-8

Thompson AE, Haryono SK. 1979. Sources of resistance to two important diseases of winged bean, Psophocarpus tetragonolobus (L.) DC HortScience. 14 (4): 532-533.
Thompson AE, Haryono SK. 1980. Winged bean: unexploited tropical food crop. HortScience 15 (3): 233-237.

Wong KC. 1980. Agronomy of the winged bean in Malaysia. In: The Winged Bean. Papers Presented in the 1st International Symposium on Developing the Potentials of the Winged Bean, January 1978, Manila. Philippine Council for Agriculture Resources Research, Los Banos, Laguna, Philippines.

Wong KC. 1983. Effects of Daylength, Temperature, Light Intensity and Applied Growth Substances on the Growth, Flowering and Tuberization of Winged Bean (Psophocarpus tetragonolobus (L.) DC). [Dissertation]. Universiti Putra Malaysia, Selangor. 